\title{
What Is Integrative Medicine?
}

\author{
Seungpil Jung \\ Department of Family Medicine, College of Medicine, Yeungnam University, Daegu, Korea
}

The demand for complementary and alternative medicine (CAM) is increasing worldwide. High-technology medicine is not always effective and is often accompanied by neglected self-care and high cost. Also, conventional medicine has become dependent on expensive technological solutions to health problems. Integrated medicine is not simply a synonym for complementary medicine. It involves the understanding of the interaction of the mind, body, and spirit and how to interpret this relationship in the dynamics of health and disease. Integrative medicine shifts the orientation of the medical practice from a disease-based approach to a healingbased approach. In South Korea, CAM education was first provided 20 years ago, and integrative medicine is becoming part of the current mainstream medicine. Increasing numbers of fellowships in integrative medicine are being offered in many academic health centers in the U.S. Also, it has emerged as a potential solution to the American healthcare crisis and chronic diseases, which are bankrupting the economy. It provides care that is patient-centered, healing-oriented, emphasizes the therapeutic relationship, and uses therapeutic approaches originating from conventional and alternative medicine.

Key Words: Integrative medicine, Complementary medicine, Alternative medicine, Holistic health, Mind-body medicine

\section{INTRODUCTION}

The demand for complementary and alternative medicine (CAM) is increasing worldwide. High-technology medicine is not always effective and is often accompanied by neglected self-care and high cost. Several studies have demonstrated the widespread use and marked growing consumer market related to $\mathrm{CAM}^{1-3}$

In Germany-Austria-Switzerland, 40 to $80 \%$ of the cancer patients use alternative medicine besides or (less frequently) than the conventional anticancer therapy. ${ }^{4}$ It was reported that $33 \%$ of the Americans were using alternative therapies such as relaxation techniques, chiropractic methods, massage, and dietary supplements, and the use of these therapies was highest among the most educated. These therapies were

Received: October 4, 2013, Revised: October 26, 2013, Accepted: November 6, 2013

Corresponding Author: Seungpil Jung, Department of Family Medicine, College of Medicine, Yeungnam University, 170, Hyeonchung-ro, Namgu, Daegu 705-703, Korea Tel: 82-53-620-3540, Fax: 82-53-654-2413

E-mail: spjung@ynu.ac.kr rarely prescribed by physicians, and most of the patients did not tell their physician that they were using these alternative therapies. ${ }^{5}$ More and more patients seek integrative medicine practitioners. By 2007, approximately 40\% of all adult Americans had used CAM therapies compared with 33\% in 1991, and one in nine children (11.8\%) used CAM therapies in 2007.6

The number of U.S. hospitals offering integrative therapies like acupuncture, massage therapy, therapeutic touch, and guided imagery has increased from $8 \%$ in 1998 to $42 \%$ in 2010. ${ }^{7}$ Recent surveys have shown that CAM is widely used in South Korea, with its use ranging from 29\% to 53\% among various patient populations. ${ }^{8-9}$ CAM also accounts for a large share of the healthcare costs, and approximately $29 \%$ of the out-of-pocket healthcare expenditure in South Korea is for CAM therapies. ${ }^{8}$

Many academic cancer centers offer these integrative practices as part of a full spectrum of care. Other hospitals offer programs in integrative women's health, cardiology, and pain management. Integrative medicine has been defined as 'the practice of medicine that reaffirms the importance of the relationship between the practitioner and the patient, focuses 
on the whole person, is informed by evidence, and makes use of all appropriate therapeutic approaches, healthcare professionals, and disciplines to achieve optimal health and healing. ${ }^{10}$

The National Center for Complementary and Alternative Medicine, which was established in 1998, provides the funds to conduct appropriate trials of these therapies. They have also funded education research and programs in both the conventional medical nursing schools and the complementary and alternative medicine professional schools. The outcomes of these studies are being published in the conventional medical literature. ${ }^{11}$

\section{EDUCATION OF INTEGRATIVE MEDICINE}

In response to the increasing demand for CAM, medical schools are incorporating CAM into their curricula. Many physicians, including those in South Korea, feel that they lack sufficient knowledge of the safety and efficacy of CAM, and wish to receive more education on the CAM modalities. ${ }^{12-14}$ In addition, medical students want to learn more about CAM during their undergraduate studies. ${ }^{15}$

In South Korea, CAM education was first provided 20 years ago. Oriental medicine, which can be considered a component of CAM, was formally incorporated into the conventional Western medicine curriculum in 1992. Currently, the Korean Institute of Medical Education and Evaluation (KIMEE) recommends the inclusion of CAM courses in basic medical education. CAM education for the medical students in South Korea, however, is uneven and not well integrated into the mainstream health education. Table 1 shows the organizational aspects of the courses, and Table 2 summarizes the categories of the South Korean medical-school CAM courses. ${ }^{16}$

In the United States, integrative medicine began to have an impact on medical education when eight medical-school deans met in 1999 to discuss complementary and alternative medicine, and when the number of medical schools that included CAM education as a required course increased from 75 of the 117 surveyed schools (64\%) in 1998 to 113 of the 126 surveyed schools (90\%) in 2008. ${ }^{17,18}$ In Canada, a study conducted in the late 1990s reported that even then, 12 of the nation's medical schools (75\%) incorporated CAM courses into the undergraduate medical curricula. ${ }^{19}$ A more recent study reported that $40 \%$ of the European medical schools provide CAM courses. ${ }^{20}$ According to a survey of Japanese medical schools in 2001, 16 schools (20\%) had introduced CAM into the curriculum. ${ }^{21}$

Table 1. Prevalence and administrative characteristics of complementary and alternative medicine education in Korean medical schools

\begin{tabular}{lc}
\hline School and course characteristics & Number (\%) \\
\hline School responding to education survey & $41(100)$ \\
Schools with $\geq 1$ course & $35(85.4)$ \\
on complementary medicine topics & \\
Required course & $34(97.1)$ \\
Elective course & $1(2.9)$ \\
Academic credit & \\
Yes & $32(91.4)$ \\
No & $3(8.6)$ \\
\hline
\end{tabular}

Table 2. Content of complementary and alternative medicine (CAM) courses offered at 35 Korean medical schools

\begin{tabular}{|c|c|c|}
\hline Topics & Number & $\%$ \\
\hline $\begin{array}{l}\text { Introduction of CAM } \\
\text { or integrative medicine }\end{array}$ & 31 & 88.6 \\
\hline Mind-body medicine & 18 & 51.4 \\
\hline Acupuncture & 10 & 28.6 \\
\hline Tai chi & 3 & 8.6 \\
\hline Meditation & 2 & 5.7 \\
\hline Yoga & 2 & 5.7 \\
\hline Relaxation & 2 & 5.7 \\
\hline Qigong & 2 & 5.7 \\
\hline Hypnotherapy & 1 & 2.9 \\
\hline Not specified & 9 & 25.7 \\
\hline Natural products & 15 & 42.9 \\
\hline Herbal medicines (botanicals) & 3 & 8.6 \\
\hline Probiotics & 3 & 8.6 \\
\hline $\begin{array}{l}\text { Others (nutritional) } \\
\text { supplements body-based practices }\end{array}$ & 11 & 31.4 \\
\hline Manipulative and body-based practices & 13 & 37.1 \\
\hline Spinal manipulation & 9 & 25.7 \\
\hline Massage & 2 & 5.7 \\
\hline Not specified & 3 & 8.6 \\
\hline Other CAM practices & 23 & 65.7 \\
\hline Traditional Korean medicine & 20 & 57.1 \\
\hline Homeopathy and naturopathy & 11 & 31.4 \\
\hline Energy field & 2 & 5.7 \\
\hline $\begin{array}{l}\text { Other (psychoneuroimmunology, } \\
\text { art therapy, mesotherapy, } \\
\text { placenta therapy, Pilates, energy, } \\
\text { aroma therapy, other) }\end{array}$ & 10 & 28.6 \\
\hline
\end{tabular}




\section{RESEARCH ON INTEGRATIVE MEDICINE}

The first international research conference on integrative medicine was held in 2006, with subsequent research conferences being held in 2009 and 2012. ${ }^{22}$ Within conventional care, some multidisciplinary approaches to patient care have already laid a foundation for the more fully integrative medicine that could emerge: for example, in geriatrics, developing multidisciplinary special-care teams ${ }^{23}$ and end-of-life programs to optimize the quality of life in hospice $\mathrm{care}^{24}$; in chronic pain treatment programs, applying multidisciplinary care to improve individual self-efficacy and quality of life ${ }^{25}$; in psychiatry, blending social support, psychotherapy, and medications $^{26}$ as well as emphasizing the patient's responsibility for his or her own recovery ${ }^{27}$; in family medicine, valuing good physician-patient relationships ${ }^{28}$ and preventive interventions $^{29}$; and in behavioral medicine/health psychology, using behavioral interventions to foster self-care and selfefficacy in patients with diabetes ${ }^{30}$ or arthritis. ${ }^{31}$

Healthcare outcomes research is an emerging field. ${ }^{32}$ It contributes substantially to the knowledge base of medicine and health care and provides the data necessary for health policy makers. ${ }^{33}$

\section{CONCLUSIONS}

Integrative medicine is not a combination medicine (CAM added to the conventional), but a whole-person-approach medicine, designed to treat the person, not just the disease. The whole system includes the patient-provider relationship, multiple conventional and CAM treatments, and the philosophical context of care as the intervention. Clinicians and researchers are increasingly using the term integrative medicine to refer to the merging of complementary and alternative medicine (CAM) with conventional biomedicine.

Despite the increasing number of patients seeking alternative therapies, until recently, many of these skills were not routinely offered in medical schools or graduate medical education, yet they are critical competencies and are essential to stemming the tide of chronic diseases that are threatening to overwhelm both the current healthcare and financial systems. Integrative medicine is becoming part of the current mainst- ream medicine. Increasing numbers of fellowships in integrative medicine are being offered in many academic health centers in the U.S.

Now on the horizon is a more pluralistic, pragmatic approach to medicine that is patient-centered, offers the broadest range of potential therapies, and advocates not only the holistic treatment of disease but also prevention, health, and wellness. ${ }^{34}$

\section{REFERENCES}

1. Xue CC, Zhang AL, Lin V, Da Costa C, Story DF. Complementary and alternative medicine use in Australia: a national population-based survey. J Altern Complement Med 2007;13: 643-50.

2. Rössler W, Lauber C, Angst J, Haker H, Gamma A, Eich D, et al. Ajdacic-Gross V. The use of complementary and alternative medicine in the general population: results from a longitudinal community study. Psychol Med 2007;37:73-84.

3. Hyodo I, Amano N, Eguchi K, Narabayashi M, Imanishi J, Hirai $\mathrm{M}$, et al. Nationwide survey on complementary and alternative medicine in cancer patients in Japan. J Clin Oncol 2005;23:2645-54.

4. Molassiotis A, Fernadez-Ortega P, Pud D, Ozden G, Scott JA, Panteli V, et al. Use of complementary and alternative medicine in cancer patients: a European survey. Ann Oncol 2005; 16:655-63.

5. Eisenberg DM, Kessler RC, Foster C, Norlock FE, Calkins DR, Delbanco TL. Unconventional medicine in the United States. Prevalence, costs, and patterns of use. N Engl J Med 1993;328:246-52.

6. Barnes PM, Bloom B, Nahin RL. Complementary and alternative medicine use among adults and children: United States, 2007. Natl Health Stat Report 2008;10:1-23.

7. Ananth S, Martin W. Health forum 2005 complementary and alternative medicine survey of hospitals: summary of results. Chicago: Health Forum LLC; 2006.

8. Lee SI, Khang YH, Lee MS, Koo HJ, Kang W, Hong CD. Complementary and alternative medicine use in Korea: prevalence, pattern of use, and out-of-pocket expenditures. Korean J Prev Med 1999;32:546-55. Korean.

9. Chae BJ, Song BJ, Kim SS, Kim SK, Jun KH, Song KY, et al. Use of complementary and alternative medicine by gastric cancer patients. J Korean Surg Soc 2007;72:369-78. Korean.

10. Consortium of Academic Health Centers for Integrative Medicine (CAHCIM). Minneapolis: CAHCIM [Internet]. [Cited 2013 October 12]. Available from: http://www.imconsortium.org.

11. CAM Research Education Partnership Project. Bloomington: Northwestern Health Sciences University [Internet]. [Cited 2013 October 12]. Available from: http://nccam.nih.gov/node/ 4568 ? nav $=$ gsa.

12. Schachter L, Weingarten MA, Kahan EE. Attitudes of family physicians to nonconventional therapies. a challenge to science 
as the basis of therapeutics. Arch Fam Med 1993;2:1268-70.

13. Berman BM, Singh BK, Lao L, Singh BB, Ferentz KS, Hartnoll SM. Physicians' attitudes toward complementary or alternative medicine: a regional survey. J Am Board Fam Pract 1995; 8:361-6.

14. Kang SW, Ha TG, Cho BH, Lee SC, Han DS, Lee KM, et al. Comparison of knowledge, attitude, and experience about complementary and alternative medicine between primary care physicians and academic physicians in Korea. J Korean Med Assoc 2011;54:217-29.

15. Chaterji R, Tractenberg RE, Amri H, Lumpkin M, Amorosi SB, Haramati A. A large-sample survey of first- and second-year medical student attitudes toward complementary and alternative medicine in the curriculum and in practice. Altern Ther Health Med 2007;13:30-5.

16. Kim DY, Park WB, Kang HC, Kim MJ, Park KH, Min BI, et al. Complementary and alternative medicine in the undergraduate medical curriculum: a survey of Korean medical schools. J Altern Complement Med 2012;18:870-4.

17. Wetzel MS, Eisenberg DM, Kaptchuk TJ. Courses involving complementary and alternative medicine at US medical schools. JAMA 1998;280:784-7.

18. American Association of Medical Colleges. U.S. medical schools teaching selected topics: 2008 LCME Part II Annual Medical School Questionnaire [Internet]. 2008 [cited 2013 Ocober 12]. Available from: http://services.aamc.org/currdir/ section2/04 05hottopics.pdf.

19. Ruedy J, Kaufman DM, MacLeod H. Alternative and complementary medicine in Canadian medical schools: a survey. CMAJ 1999;160:816-7.

20. Varga O, Márton S, Molnár P. Status of complementary and alternative medicine in European medical schools. Forsch Komplementmed 2006;13:41-5.

21. Tsuruoka K, Tsuruoka Y, Kajii E. Complementary medicine education in Japanese medical schools: a survey. Complement Ther Med 2001;9:28-33.

22. Consortium of Academic Health Centers for Integrative Medi- cine. Past research events [Internet]. [Cited 2013 October 12]. Available from: http://www.imconsortium.org/pastresearchevents.

23. Burns R, Nichols LO, Martindale-Adams J, Graney MJ. Interdisciplinary geriatric primary care evaluation and management: two-year outcomes. J Am Geriatr Soc 2000;48:8-13.

24. Bretscher M, Rummans T, Sloan J, Kaur J, Bartlett A, Borkenhagen L, et al. Quality of life in hospice patients. a pilot study. Psychosomatics 1999;40:309-13.

25. Merboth MK, Barnason S. Managing pain: the fifth vital sign. Nurs Clin North Am 2000;35:375-83.

26. Rydman RJ, Trybus D, Butki N, Kampe LM, Marley JA. Outcome of case management and comprehensive support services following policy changes in mental health care delivery. J Med Syst 1999;23:309-23.

27. Thiels C, Schmidt U, Treasure J, Garthe R, Troop N. Guided self-change for bulimia nervosa incorporating use of a selfcare manual. Am J Psychiatry 1998;155:947-53.

28. Marvel MK, Doherty WJ, Weiner E. Medical interviewing by exemplary family physicians. J Fam Pract 1998;47:343-8.

29. Ferguson RS. Preventive care in daily practice. J Okla State Med Assoc 2000;93:154-60.

30. Anderson RM, Funnell MM, Fitzgerald JT, Marrero DG. The diabetes empowerment scale: a measure of psychosocial selfefficacy. Diabetes Care 2000;23:739-43.

31. Lorig K, Seleznick M, Lubeck D, Ung E, Chastain RL, Holman HR. The beneficial outcomes of the arthritis self-management course are not adequately explained by behavior change. Arthritis Rheum 1989;32:91-5.

32. Kane RL. Understanding health care outcomes research. Gaigthersburg, Md: Aspen Publishers. Inc; 1997.

33. Bell IR, Caspi O, Schwartz GE, Grant KL, Gaudet TW, Rychener D, et al. Integrative medicine and systemic outcomes research: issues in the emergence of a new model for primary health care. Arch Intern Med 2002;162:133-40.

34. Sierpina VS, Dalen JE. The future of integrative medicine. Am J Med 2013;126:661-2. 